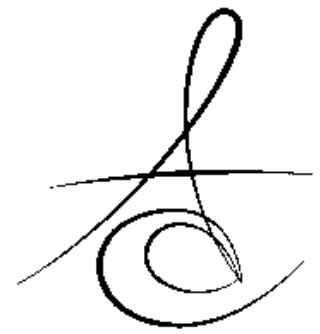

\title{
DENTAL REZİN KOMPOZİTLERİN SİTOTOKSİSİTESİ: BİR İN VİTRO ÇALIŞMA
}

\section{CYTOTOXICITY OF DENTAL RESIN COMPOSITES: AN IN VITRO STUDY}

Arş. Gör. Dr. Tevfik DEMİRCi*

Doç. Dr. Taşkın GÜRBÜZ*

Yrd. Doç. Dr. Fatih ŞENGÜL*

\section{ÖZET}

Amaç: $\mathrm{Bu}$ çalışmada iki farklı restoratif rezin materyalin (Clearfil Majesty ${ }^{\circledR}$ ve Grandio Flow ${ }^{\circledR}$ ) insan fibroblast hücreleri üzerinde zamanla meydana getirdikleri sitotoksik etkilerin MTT [3-(4,5 DimetilTiazol-2)-2,5 DifenilTetrazolyum Bromit] testi ile değerlendirilmesi amaçlanmıştır.

Materyal ve Metot: Çalışmada insan amniyon hücresinden alınan fibroblastlar kullanılmıştır. Örnekler $8 \mathrm{~mm}$ çapında $2 \mathrm{~mm}$ yüksekliğinde hazırlanmıştır ve platelere aktarılan hücrelerle doğrudan temas edecek şekilde eklenmiştir. Kontrol grubuna ise herhangi bir materyal yerleştirilmemiştir. MTT testi ile 24 saat, 72 saat ve 7 gün sonunda gözlerdeki hücrelerin canlılığına bakılmıştır.

Bulgular: MTT testi sonuçlarına göre kullanılan materyallerin 24 saat, 72 saat ve 7 gün sonunda hücre canlıı̆̆ını istatistiksel olarak anlamlı ölçüde azalttığı tespit edilmiştir. MTT değerlerine göre 24 saat, 72 saat ve 7 gün sonunda her iki materyal de toksik bulunmuştur.

Sonuç: Rezin esaslı materyallerin doldurucu içeriği ve oranı, sitotoksik etkileri açısından önemli olduğundan materyal seçiminde dikkate alınmalıdır.

Anahtar Kelimeler: Hücre Kültürü, MTT, Rezin Monomerler, Sitotoksisite

\section{INTRODUCTION}

Restoratif materyaller diş dokusuna uygulandığında, pulpanın canlılığını devam ettirebilmesi için uygulanan materyalin toksik olmaması ve bakteri penetrasyonunu engelleyecek şekilde diş dokusuna uzun süreli hermetik bir bağlanma sağlaması

\section{ABSTRACT}

Objective: The objective of this in vitro study was to evaluate the cytotoxic effects of two different resin based restorative meterials (Clearfil Majesty ${ }^{\circledR}$ ve Grandio Flow $^{\circledR}$ ) on human fibroblast cells via MTT [3(4,5Dimethylthiazol-2)-2,5 Diphenyltetrazolium bromide] test.

Material and Methods: Fibroblast cells derived from human amniotic fluid were used in this study. The samples prepared in $2 \mathrm{~mm}$ height and $8 \mathrm{~mm}$ diameter were placed into each of the wells in direct contact with the cell culture. None of the test materials was placed into the control group wells. The vitality rate of the cells was evaluated at the end of 24 hours, 72 hours and 7 days by means of MTT test results.

Results: According to MTT findings, at the end of 24 hours, 72 hours and 7 days the decrease caused by the used materials in the number of the cells was ststistically significant. Both materials used found to be cytotoxic after 24 hours, 72 hours and 7 days.

Conclusion: As the ingredients and filler rates of resin containing materials are important for cytotoxic effects, these specialities should be considered for material selection.

Key Words: Cell Culture, Cytotoxicity, MTT, Resin Monomers,

gerekmektedir. ${ }^{1-3}$ Adeziv diş hekimliği, restorasyonlarda materyalin dişe daha iyi bağlanabilmesi nedeniyle konservatif yaklaşım sağladığı ve bu yöntemde kullanılan materyallerin diş rengine benzer renklerde olduğu için daha fazla tercih edilmektedir. ${ }^{4}$ Bununla birlikte rezin esaslı restoratif materyallerin büyük ölçüde toksik etkiye neden olan maddeleri saldıklarını bildiren çok sayıda çalışma bulunmaktadır. ${ }^{5-8}$

\footnotetext{
${ }^{*}$ Atatürk Üniversitesi, Diş Hekimliği Fakültesi, Pedodonti A.B.D
} 
Restoratif materyallerin pulpaya olan etkisinin restorasyonun altındaki dentinin geçirgenliği ile ilişkili olduğu ifade edilmiştir. ${ }^{9,} 10$ Restoratif materyaller, ani veya uzun süreçte sitotoksik etki göstererek veya hipersensitivite reaksiyonlarını uyararak pulpaya zarar verebilirler. Polimerize olabilen organik matriks, doldurucular, doldurucuları ve organik matriksi birleştiren silan bağlantı ajanları, polimerizasyon reaksiyonlarını başlatan ve modifiye eden moleküller ve doldurucuları güçlendiren seramik partiküllerden oluşan kompozitler başta olmak üzere rezin içerikli restoratif materyallerin bazı bileşenlerinin, polimerizasyon tamamlandıktan sonra da sitotoksik etki gösterdiği ve pulpada uzun süreli stimülasyonla inflamatuar cevaba yol açabildiği bildirilmiştir. ${ }^{11}$

Rezin bazlı bir restoratif materyalin biyouyumluluğunun saldığı organik maddelerin miktarı ve yapısıyla ilişkili olduğ ${ }^{12}$ ve zamanla, yetersiz polimerizasyon veya çözünmelere bağlı olarak rezin matriksten salınan bu maddelerin sitotoksik sonuçlar oluşturabileceği belirtilmiştir. ${ }^{12,13}$

Restoratif materyallerin biyouyumluluğunu değerlendiren araştırmalarda çeşitli test yöntemleri kullanılmakla birlikte yaygın olarak hayvan deneyleri ve hücre kültür testleri kullanılmaktadır. ${ }^{14,}{ }^{15}$ Hücre kültür test yöntemleri daha iyi standardize edilebilir ve tekrarlanabilir özellikte olmakla birlikte hayvan deneylerine kıyasla, uygulaması kolay, daha az zaman alan ve ekonomik testler oldukları için hayvan deneylerine tercih edilmektedirler. ${ }^{16}$

Çalışmamızın amacı, ışıkla sertleşen iki farklı rezin restoratif materyalinin (Clearfil Majesty Esthetic ${ }^{\circledR}$ ve Grandio $\mathrm{Flow}^{\circledR)}$ insan fibroblast hücreleri üzerinde zamanla meydana getirdikleri sitotoksik etkileri, in vitro olarak direk temas yöntemiyle ve MTT testi ile ortaya koymaktır.

\section{MATERYAL VE METOD}

Bu çalışma, Atatürk Üniversitesi Bilimsel Araştırma Projeleri Koordinatörlüğü (BAP) tarafından (2011/34) desteklenmiş ve Atatürk Üniversitesi Sağlık Bilimleri Etik Kurul Başkanlığı́nın (30.06.2011 tarih ve 2011.3.1/1 sayılı) izni ve etik kurul onayı ile Atatürk Üniversitesi Tıp Fakültesi Tıbbi Genetik Anabilim Dalı ve Tıbbi Farmakoloji Anabilim Dalı laboratuarlarında yürütülmüştür.
Çalışmada iki farklı kompozit rezin materyalin hücre kültürü üzerine zamana bağlı sitotoksik etkileri araştırılmıştır (Tablo 1). Bu amaç için in vitro sitotoksisite testlerinden direkt temas test yöntemi ve hücre canlıı̆ı̆ı belirleyen MTT testi kullanılmıştır.

Tablo 1. Çalışmada kullanılan materyaller, içerikleri ve üretici firmalar

\begin{tabular}{lll}
\hline Materyal & Firma & İçerik \\
\hline Clearfil & Kuraray & $\begin{array}{l}\text { Bis-GMA, Hydrophobic aromatic } \\
\text { dimethacrylate } \\
\text { Hydrophobic aliphatic methacrylate, } \\
\text { Silanated barium glass filler Pre- } \\
\text { polymerized organic filler dl- } \\
\text { Camphorquinone, Initiators, } \\
\text { Accelerators, Pigment } \\
\text { (poly)methylene dimethacrylate } \\
\text { (HEDMA), Bis-GMA, TEGDMA, BHT }\end{array}$ \\
\hline
\end{tabular}

\section{Örneklerin Hazırlanması}

Polimerize edilmemiş test materyalleri, özel olarak hazırlanmış olan teflon bir kalıp ( $8 \mathrm{~mm}$ çapında ve $2 \mathrm{~mm}$ kalınlığında) içerisine yerleştirilmiş ve oksijen inhibisyonunu engelleyecek şekilde her iki yüzeyden de şeffaf bantlarla ve düzgün yüzeyli camlarla baskılanmıştır. Üretici firmaların önerilerine göre $450 \mathrm{~nm}$ dalga boyunda görülebilir mavi LED ışık ile (Elipar ${ }^{\mathrm{TM}} \mathrm{S} 10$ FreeLight 2 LED Curing Light, 3M ESPE), tek bir ışık kaynağıyla bir yüzeyden ve $2 \mathrm{~mm}$ mesafeden $40 \mathrm{~s}$ süre ile polimerize edilmiştir. Örneklerin yüzey alanının solüsyon hacmine oranı, ISO standartlarının önerdiği 0.5-6.0 $\mathrm{cm}^{2} / \mathrm{ml}$ aralığına uygun bir biçimde yaklaşık $3.17 \mathrm{~cm}^{2} / \mathrm{ml}$ olarak ayarlanmıştır. Işık kaynağının ışın yoğunluğu $1200 \mathrm{~mW} / \mathrm{cm}^{2}$, ışık ucunun başlangıç çapı $10 \mathrm{~mm}$ ve son çapı $8 \mathrm{~mm}$ 'dir. Hazırlanan materyaller 48 gözlü platelerin altışar gözüne yerleştirilmeden önce; otoklavda, $121^{\circ} \mathrm{C}^{\prime}$ de, 1 atmosfer basınçta ve 15 dakika basınçı buhar ile sterilize edilmiştir.

\section{MTT Testi}

Çalışmada, rutin genetik kontroller için Atatürk Üniversitesi Tıp Fakültesi Tıbbi Genetik Anabilim Dalı'na başvuran bireylerden, ebeveyn oluruyla elde edilen amniyon sıvısının ihtiyaten bekletilen kısımları, ön incelemelerde sonuç alındıktan ve genetik olarak bireyin normal olduğu belirlendikten sonra, atılacak olan amniyon sıvısından hazırlanan insan fibroblast hücreleri kullanılmıştır. Çözünmüş stok halindeki hücreler $5 \mathrm{dk}$. süreyle 800 devirde santrifüj 
(Herause,Germany) edilmiştir. Santrifüj sonrası, yüzeydeki süpernatan kısım atılarak pellet içerisindeki hücreler, içinde $\% 10$ fetal sığır serumu (FBS) (Biochrom AG, Germany, SO113) ve \%1 gentamisin içeren Dulbecco Modified Eagle's Medium- DMEM (Hyclone, England, AQF24057) besi ortamı ile $25 \mathrm{~cm}^{2}$ hücre kültürü üretme kabına (flask) alınmıştır. Bir hafta sonunda inverted mikroskop (Olympus CK 40, Japan) ile hücrelerin flask tabanını kaplayıp kaplamadıkları ve sağlıklı bir şekilde üreyip üremedikleri kontrol edilmiştir. Hücreler flask tabanını tamamen kapladıklarında kültür kabındaki besi yeri (medyum) aspire edilmiştir. Divalent katyonları $(\mathrm{Ca},++; \mathrm{Mg}++)$ içermeyen fosfat tampon solüsyonu (PBS) $(\mathrm{pH}=7.0)$ ile hücrelerin yüzeyi yıkanmıştır. Kültür daha sonra tripsin / etilendiamin tetraasetik asit (EDTA) (\%0.05 \%0.02, Biochrom AG, Germany) solüsyonu ile yıkanarak $37{ }^{\circ} \mathrm{C}$ ve \%5 kısmi $\mathrm{CO}_{2}$ basıncındaki inkübatörde (NuAire, Inc. Plymouth, U.S.A.) yaklaşık olarak 5-10 dk inkübe edilmiştir. Bu süre sonunda makroskobik ve mikroskobik olarak incelenen hücrelerin flask tabanından ayrıldıkları görülmüştür. Yüzeyden ayrılan hücrelere \%10 serum içeren yeni medyum ilave edilmiş ve hücreler pipetajla karıştırıldıktan sonra $5 \mathrm{dk}$. süreyle santrifüj işlemine tutulmuşlardır. (800-1000 rpm) Süpernatan kısım atıldıktan sonra pellet içerisindeki hücreler tekrar, 37 ${ }^{\circ} \mathrm{C}$ sıcaklıkta \%10 serum ve \%1 antibiyotikli DMEM medyum ile homojenize edilmiştir. Hücre süspansiyonu platelere pasajlanmıştır.

Logaritmik üreme tarzında olan, aktif ve yüzeyi \%90-95 oranında kaplamış hücreler, pasajlama işleminde olduğu gibi flask tabanından ayrılmış ve taze medyum ile hücre süspansiyonu hazırlanmıştır. Wellplate'lerin materyallerin yerleştirileceği her bölmesine hazırlanan $200 \mathrm{ml}$ hücre süspansiyonu dağıtılmıştır. Aynı yöntemle 3 adet well-plate hazırlanmıştır. 5 . günde kültür ortamındaki DMEM medyum aspire edilerek uzaklaştırılmış ve yerine taze medyum ilave edildikten sonra tekrar $37^{\circ} \mathrm{C}^{\prime}$ deki $\quad \% 5 \quad \mathrm{CO}_{2}$ 'li inkübatörde inkübasyona bırakılmıştır. $\% 5 \mathrm{CO}_{2}{ }^{\prime l i}$ ve 37 ${ }^{\circ} \mathrm{C}$ de nemli ısıdaki 7 günlük inkübasyon süresi sonunda hücrelerin hazırlanan well-plate'deki tüm gözlerin tabanını tamamen doldurup doldurmadığı inverted mikroskop ile kontrol edilmiştir. Deney öncesinde hücrelerin gözleri tamamen doldurduğu ve fibroblast hücrelerinin karakteristik iğsi yapısı ışık mikroskobunda incelenmiştir.
Otoklavda (Lisa 300, W\&H) sterilize edilen örnekler; daha sonra, steril bir presel yardımıyla, steril kabin içerisinde teker teker ve hücrelerle doğrudan temas edecek şekilde well-plate'lere taşınmıştır. Kontrol grubu hücrelerine herhangi bir materyal yerleştirilmemiştir. $37{ }^{\circ} \mathrm{C}^{\prime}$ deki \%5 $\mathrm{CO}_{2}{ }^{\prime}$ li inkübatörde 24 saat, 72 saat ve 7 günlük inkübasyon süresi sonunda MTT testi ile toksisite testine geçilmiştir. Materyallerin sitotoksisitelerinin belirlenmesi için, 'direkt temas test metodu' uygulanarak, 3-(4,5-dimetiltiazol-2-yl)-2,5Difeniltatrazilyum bromid içeren MTT maddesi ile ( Sigma Aldrich inc, St. Louis, USA) fibroblastlarda hücre canlılık oranları değerlendirilmiştir. Örnekler, absorbans, (optik yoğunluk) spektrofometrede ( Quant, Bad Friedrichshall, Biotek) 550 nm dalga boyunda ölçülerek ortamdaki canlı hücre sayısı tespit edilmiştir.

\section{İstatistiksel Değerlendirme}

Çalışmadan elde edilen değerler, ortalama ve standart sapma olarak verilmiştir. Verilerin analizi için SPSS 20.0 programı kullanılmıştır. Tespit edilen MTT değerlerinin gruplar arası zamanla değişimi için tekrarlayan ölçümlerde varyans analizi, gruplar arası farkların analizi için ise, Post-hoc LSD çoklu karşılaştırma testi kullanılmıştır. Bütün analizlerde $\mathrm{p}<0.05$ anlam düzeyi dikkate alınmıştır.

\section{BULGULAR}

İnsan fibroblast hücrelerine doğrudan temas yöntemiyle uygulanan, görülebilir mavi ışıkla sertleşebilen iki farklı kompozit rezin materyalin ve herhangi bir materyal uygulanmamış olan kontrol grubunun 24 saat, 72 saat ve 7 gün sonunda elde edilen MTT testi sonuçları, grup ortalama değerleri ve standart sapmaları Tablo 2'de verilmiştir.

Clearfil Majesty ve Grandio Flow grubunda 24 saat sonraki değerlerde, kontrol grubuna kıyasla hücre canlılığının önemli ölçüde azaldığı görülmektedir. MTT değerlerine göre 72 saat ve 7 gün sonra grupların ikisinde de toksik etki tespit edilmiştir (Şekil 1).

MTT testi sonuçlarına göre hücre canlıı̆ı bakımından 24 saat ve 7 gün sonundaki değerlendirmelerde bütün gruplar arasında istatistiksel olarak anlamlı farklılık bulunmuştur $(p<0.05)$ (Tablo 2). 72 saat sonunda ise, her iki deney grubu da kontrol grubuyla karşılaştırıldıklarında istatistiksel 
olarak anlamlı farklılık gösterirken $(p<0.001)$ kendi aralarında istatistiksel olarak anlamlı bir farklılık sergilememişlerdir ( $p=0.053$ ) (Tablo 2 ).

Tablo 2. Kullanılan 2 farklı kompozit rezin materyalin ve kontrol grubunun 24 saat, 72 saat ve 7 gün sonundaki MTT test değerlerinin ortalama ve standart sapma değerleri.

\begin{tabular}{lccc}
\hline Grup & $\begin{array}{c}\text { 24 Saat } \\
\text { Ortalama } \pm \text { SS }\end{array}$ & $\begin{array}{c}\text { 72 Saat } \\
\text { Ortalama } \pm \text { SS }\end{array}$ & $\begin{array}{c}\text { 7gün } \\
\text { Ortalama } \pm \text { SS }\end{array}$ \\
\hline Kontrol & $0.174 \pm 0.03^{\mathrm{a}}$ & $0.267 \pm 0.06^{\mathrm{a}}$ & $0.227 \pm 0.08^{\mathrm{a}}$ \\
$\begin{array}{l}\text { Clearfil } \\
\text { Majesty } \\
\text { Grandio } \\
\text { Flow }\end{array}$ & $0.058 \pm 0.02^{\mathrm{b}}$ & $0.085 \pm 0.04^{\mathrm{b}}$ & $0.004 \pm 0.0^{\mathrm{c}}$ \\
\hline
\end{tabular}

* Farklı harfler arası MTT değerlerinde istatistiksel olarak anlamlı farklııı vardır

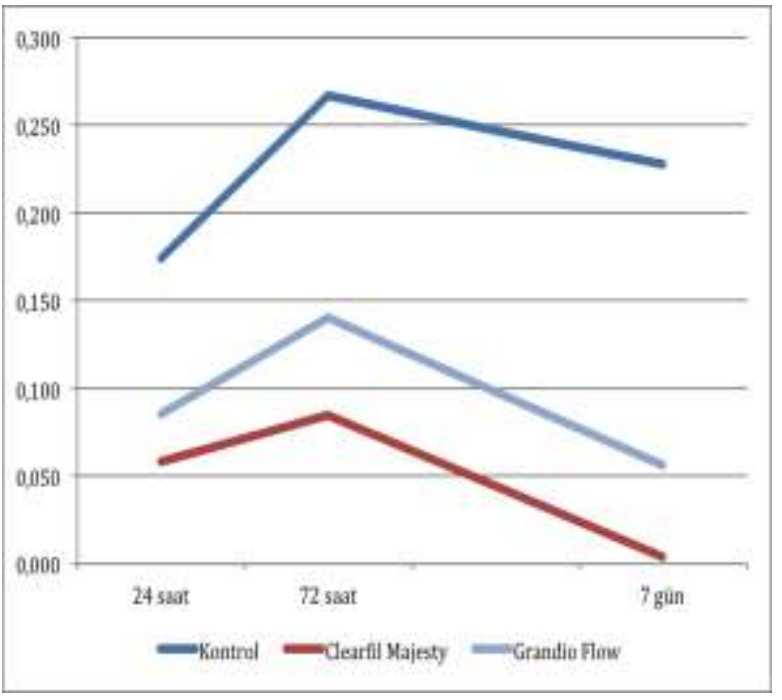

Şekil 1. MTT sonuçlarına göre hücre canlılık grafiği

\section{TARTIŞMA}

Bu çalışmanın amacı, iki farklı rezin esaslı materyalin sitotoksisitesini karşılaştırmaktır. Diş hekimliğinde kullanılan restoratif materyallerin mekanik özellikleri ile ilişkili oldukça fazla literatür bilgisi bulunurken bu materyallerin biyolojik etkileri ile ilgili veriler gelişen teknoloji ve teknikler sayesinde artmaya devam etmektedir. Bir restoratif materyal geliştirilirken, kimyasal ve mekanik özelliklerin yanında biyouyumluluğu da göz önünde bulundurulmalıdır. ${ }^{17}$ İn vivo olarak kullanıl- ması düşünülen materyallerin dokular üzerindeki toksik etkilerinin ve oluşabilecek istenmeyen doku cevaplarının değerlendirilmesi amacıyla in vitro biyouyumluluk testleri geliştirilmiştir. ${ }^{17,18}$

Hücre kültür test yöntemleri, hayvan deneylerine kıyasla uygulaması daha kolay, daha az zaman alan ve daha ekonomik testlerdir. ${ }^{16}$ Hücre kültür yöntemlerinde yaygın olarak kullanılan MTT testinin güvenilirliği yapılan çalışmalarda belirtilmiştir. ${ }^{19-21}$ Fotakis ve Timbrel122, çalışmalarında, nötral kırmııı ile MTT testlerinin sonuçlarının daha hassas olduğunu belirtmişlerdir. Bu bilgiler ışığında çalışmamızda hücre kültürü ve direkt temas yöntemleri ile MTT testi tercih edilmiştir.

Restoratif diş hekimliğinde kullanılan, polimerize olabilen bütün materyaller için yetersiz polimerizasyon nedeniyle biyolojik reaksiyon oluşturabilme riski ifade edilmiştir. ${ }^{23}$ Teorik olarak tam bir polimerizasyon mümkün gibi görünse de metakrilat monomerlerinin, \% 25-50 oranında çift bağ oluşturması ve reaktive olmadan kalmaları, bu nedenle de dentinal tübüllerden geçip, pulpaya ulaşarak biyolojik reaksiyonlara neden olabilmelerinin söz konusu olabileceği bildirilmiştir. ${ }^{23-25}$ Akıc kompozit materyaller ile yapılan bir çalışmada, kullanılan akıcı kompozit rezin materyallerin, mikrosızıntıyı tamamen elimine edemediği bu bulunmuştur. ${ }^{26}$ Yüksek polimerizasyon oranlarının yanı sıra mikrosızıntının elimine edilmesi de pulpa dokusunun korunması açısından önemlidir.

Trichaiyapon ve ark. ${ }^{27}$ akıc kompozit ve mineral trioksit agregat (MTA) materyallerin insan periodontal ligament hücreleri (PDLC) üzerine sitotoksik etkilerini karşılaştırdıkları çalışmalarında, yeni hazırlanmış olan MTA ve fluorid salımı yapabilen akıcı kompozit rezin materyalleri daha toksik, diğer akıc kompozitleri en az toksik olarak bulmuşlardır. Araştırmacıların sonuçlarını destekler nitelikte çalışmamızda da, akıcı kompozit rezin olan Grandio Flow daha az sitotoksik etki gösteren materyal olmuştur.

Çalışmamızda akıcı kompozit rezin materyali (Grandia Flow), kompozit rezinden (Clearfil Majesty) istatistiksel olarak anlamlı olmasa da daha düşük sitotoksisite göstermiştir. Bunun sebebinin, akıcı kompozit rezinin doldurucu içeriğinin diğer materyale göre daha az olması ${ }^{28}$ ve daha fazla polimerize olması sonucunda artık monomer miktarının azalması olabileceğini düşünmekteyiz. 
Son zamanlarda yapılan in vitro bir çalışmada, 48 saat yapay tükürükte bekletilen materyallerin hemen kullanılan materyallerden daha az sitotoksik etki gösterdiği bulunmuştur. ${ }^{29}$ Bununla birlikte; Gül, ${ }^{30}$ yapmış olduğu tez çalışmasında, polimerizasyondan bir ay sonra bile kompozit materyallerden ortama monomer geçişinin olduğunu bulmuştur.

Sonuç olarak, çalışmamızda kullandığımız materyallerin zamanla neden oldukları toksisite etkilerini değerlendiren ileri çalışmalara intiyaç vardır. Klinik koşullarda uygulanan rezin içerikli restorasyonların; pulpa ile aralarında dentin dokusunun bulunması ve bağlayıcı ajanların kullanılıyor olması, ağız ortamında ışık kaynakları ile yapılan polimerizasyonun farkı olması nedeniyle materyallerin sitotoksisitesi in vivo koşullarda farklılık sergileyebilir.

Özellikle derin dentin çürüklerinin restorasyonları gibi, kavite hazırlandıktan sonra kalan dentin kalınlığının az olduğu klinik koşullarda, rezin esaslı materyallerle başarılı bir restorasyon yapılsa bile, materyallerden salınabilecek monomerlerin pulpaya ulaşabileceği ve pulpa hücrelerine sitotoksik etki gösterebileceği aşikardır. Bu sebeple, rezin içerikli materyallerin biyouyumluluğunun artırımasına yönelik ileri çalışmalara intiyaç duyulmaktadır.

\section{SONUÇ}

Dental kompozitlerin farklı sitotoksik etkilerinden dolayı, restorasyon uygulamasından önce, uygun bir rezin esaslı materyal seçiminde, dikkatli olmak gereklidir. Polimerizasyon oranı yüksek olan akıcı materyallerde, polimerizasyon büzülmesi ve termal genleşme katsayı farklııklarından kaynaklanan kenar sızıntıları bu materyaller için göz önünde bulundurulması gereken özelliklerdir.

\section{TEŞEKKÜR}

Yazarlar çalışmayı, 2011/34 BAP proje numarası ile destekleyen Atatürk Üniversitesi Bilimsel Araştırma Projeleri Koordinatörlüğüne ve çalışmanın laboratuar aşamalarındaki her türlü desteklerinden ötürü, Sayın Doç. Dr. Abdulgani Tatar'a, Sayın Prof. Dr. Ahmet Hacımüftüoğlu'na ve Sayın Doç. Dr. Hasan Türkez'e teşekkür etmektedir.

\section{KAYNAKLAR}

1. Brännström $M$ and Vojinović $O$. Response of the dental pulp to invasion of bacteria around three filling materials. ASDC journal of dentistry for children. 1975; 43: 83-9.

2. Cox CF, et al. Biocompatibility of surface-sealed dental materials against exposed pulps. The Journal of prosthetic dentistry. 1987; 57: 1-8.

3. Grieve A, Alani A, and Saunders W. The effects on the dental pulp of a composite resin and two dentine bonding agents and associated bacterial microleakage. International endodontic journal. 1991; 24: 108-18.

4. Melo MAVd, et al. Effects of different surface treatments and accelerated artificial aging on the bond strength of composite resin repairs. Brazilian oral research. 2011; 25: 485-91.

5. Geurtsen W, Spahl W, and Leyhausen G. Variability of cytotoxicity and leaching of substances from four light- curing pit and fissure sealants. Journal of biomedical materials research. 1999; 44: 73-7.

6. Geurtsen W, Spahl W, and Leyhausen G. Residual monomer/additive release and variability in cytotoxicity of light-curing glass-ionomer cements and compomers. Journal of dental research. 1998; 77: 2012-9.

7. Hanks $C$, et al. Cytotoxic effects of resin components on cultured mammalian fibroblasts. Journal of dental research. 1991; 70: 1450-5.

8. Ferracane $\mathrm{J}$ and Condon $\mathrm{J}$. Rate of elution of leachable components from composite. Dental Materials. 1990; 6: 282-7.

9. Pashley $D$ and Carvalho R. Dentine permeability and dentine adhesion. Journal of dentistry. 1997; 25: 355-72.

10. Bouillaguet $S$, et al. The influence of dentine permeability on cytotoxicity of four dentine bonding systems, in vitro. Journal of oral rehabilitation. 1998; 25: 45-51.

11. Cohen $S$, et al. Pathways of the pulp. Elsevier Mosby: 2006.

12. Geurtsen W. Biocompatibility of resin-modified filling materials. Critical Reviews in Oral Biology \& Medicine. 2000; 11: 333-55.

13. Ferracane J. Elution of leachable components from composites. Journal of oral rehabilitation. 1994; 21: 441-52. 
14. Murray PE, García Godoy C, and García Godoy F. How is the biocompatibilty of dental biomaterials evaluated? Medicina Oral, Patología Oral y Cirugía Bucal (Internet). 2007; 12: 258-66.

15. Tuncer S DM. Dental Materyallerde Biyouyumluluk Değerlendirmeleri. Atatürk Üniv. Diş Hek. Fak. Derg. 2011; 21: 141-9.

16. Schmalz G, et al. Dentin barrier test with transfected bovine pulp-derived cells. Journal of endodontics. 2001; 27: 96-102.

17. Hanks CT, Wataha JC, and Sun Z. In vitro models of biocompatibility: a review. Dental materials : official publication of the Academy of Dental Materials. 1996; 12: 186-93.

18. Williams DF and Smith DC. Biocompatibility of dental materials. CRC series in biocompatibility. Boca Raton, Fla.; CRC Press: 2002.

19. Cao T, et al. Comparison of different test models for the assessment of cytotoxicity of composite resins. Journal of Applied Toxicology. 2005; 25: 101-8.

20. Taoufik K, et al. Effect of blue light on the proliferation of human gingival fibroblasts. Dental Materials. 2008; 24: 895-900.

21. Ergün G, et al. Effect of light curing type on cytotoxicity of dentine- bonding agents. International endodontic journal. 2007; 40: 21623.

22. Fotakis $G$ and Timbrell JA. In vitro cytotoxicity assays: comparison of LDH, neutral red, MTT and protein assay in hepatoma cell lines following exposure to cadmium chloride. Toxicology letters. 2006; 160: 171-7.

23. Zorba YO, et al. Reactions of connective tissue to self-etching/priming dentin bonding systems: oxidative stress, tumor necrosis factor a expression, and tissue reactions. Journal of Dental Sciences. 2009; 4: 136-48.

24. Imazato $S$, et al. Degree of conversion of composites measured by DTA and FTIR. Dental Materials. 2001; 17: 178-83.

25. Hume $W$ and Gerzina T. Bioavailability of components of resin-based materials which are applied to teeth. Critical Reviews in Oral Biology \& Medicine. 1996; 7: 172-9.
26. Sadeghi M. An in vitro microleakage study of class $\checkmark$ cavities restored with a new self-adhesive flowable composite resin versus different flowable materials. Dent Res J (Isfahan). 2012; 9: 460-5.

27. Trichaiyapon V, Torrungruang $K$, and Panitvisai $P$. Cytotoxicity of flowable resin composite on cultured human periodontal ligament cells compared with mineral trioxide aggregate. Journal of Investigative and Clinical Dentistry. 2012; 3: 215-20.

28. Ferracane JL. Resin composite-State of the art. Dental Materials. 2011; 27: 29-38.

29. Yildirim-Bicer $A Z$, et al. In vitro cytotoxicity of indirect composite resins: Effect of storing in artificial saliva. Indian J Dent Res. 2013; 24: 81-6.

30. Pınar G, Kompozit Dolgu Maddesinden Zamanla Salınan Artık Monomer Miktarları ve bu Monomerlerin Tükürük MDA Düzeyi ve Bazı Antioksidan Enzim Seviyeleri Üzerine Etkileri. Diş Hastalıkları ve Tedavisi Anabilim Dalı.2012, Atatürk Üniversitesi: Erzurum.

\section{Yazışma Adresi:}

Yrd. Doç. Dr. Tevfik DEMİRCİ

Atatürk Üniversitesi

Diş Hekimliği Fakültesi

Pedodonti A.B.D.

Erzurum, Turkiye

Tel.: 0904422311777

Fax:090 4422360945

E-mail: tevfik2111@gmail.com 